first observations on their commercial samples initiated the present work ; further, I wish to thank Dr. A. F. Wells for his interest and help.

Imperial Chemical Industries, Ltd., A. Keller Dyestuffs Division,

Hexagon House, Blackley, Manchester 9.

${ }^{1}$ Keller, A., J. Polymer Sei. (in the press).

${ }^{2}$ Holmes, D. R., Miller, R. G., Palmer, R. P., and Bunn, C. W., Nature, 171, 1104 (1953).

\section{A Simple Microtitration Method for the Determination of Calcium and Magnesium in the Hremolymph of Insects}

According to several authors ${ }^{1,2}$, the direct titration of calcium and magnesium with ethylenediamine tetraacetate has yielded very good results, especially in the determination of water hardness and in elinical investigations of blood plasma. Since other methods described for the determination of calcium and magnesium are rather laborious, and micro-scale determination is liable to large errors, we have tried the direct titration with ethylenediamine tetraacetate using the well-known Linderstrøm-Lang micro-titration technique. Determinations have been carried out on some species of Blattaria : Periplaneta americana, Periplaneta australasiae and Blabera fusca.

A small amount of hæmolymph $(5-20 \mu l$.) is obtained from the insects by puncturing the ventral side of thorax or abdomen. The light yellow hæmolymph appearing on the wound is sucked up in a capillary pipette, and blown out into a small titration vessel (capacity $c .500 \mu l$.) and immediately diluted with distilled water $(c .100 \mu l$.$) . After bringing the$ mixture to the appropriate $p \mathrm{H}$ with sodium hydroxide and, in the case of magnesium titration, adding a buffer solution, the indicator is added and titration carried out. Murexide is used as an indicator for the presence of unchelated calcium, whereas eriochromeblack $T$ is used to indicate the presence of unchelated magnesium.

As ethylenediamine tetraacetate has a much greater affinity for calcium than for magnesium, the calcium concentration may be calculated from the amount of the reagent used in the murexide titration, whereas the sum of calcium and magnesium can be found by performing an eriochrome-black titration; the mag nesium concentration is therefore obtained by subtraction. Calculations are very simple since one mole of ethylenediamine tetraacetate chelates one mole of divalent cation.

The reliability of the method was tested by performing determinations of calcium and magnesiurn in solutions containing known amounts of calcium chloride and/or magnesium sulphate, in human sera to which known amounts of magnesium sulphate had been added, in samples from pooled hæmolymph, in samples taken successively from the same insect and in hæmolymph to which known amounts of magnesium sulphate had been added. Moreover, the results of micro-titration were compared with those of macro-titration with ethylenediamine tetraacetate and in a few cases with those of the calcium-oxalate precipitation method. The results of these checking experiments were quite satisfactory.

A large number of determinations have been carried out on hæmolymph of single individuals of Peri. planeta americana, and some for $P$. australasiae and Blabera fusca (see Table 1). From these data it may be concluded that the intraspecific as well as the interspecific differences are rather small, especially in the case of calcium. Sex differences are not significant. The ratio calcium/magnesium is about the same for all three species.

\begin{tabular}{|c|c|c|c|}
\hline Species & $\underset{(\mathrm{mgm} . \text { per }}{\text { Calciumm }}$ & $\begin{array}{l}\text { Magnesium* } \\
\text { gm. of hæmo- } \\
\text { gh) }\end{array}$ & $\underset{\text { ratio } \dagger}{\text { Calcium } /}$ \\
\hline $\begin{array}{l}\text { P. americana } \\
P \text {. australusiae } \\
\text { Blabera fusca }\end{array}$ & $\begin{array}{r}(107) 17 \cdot 8+1 \cdot 9 \\
\text { (17) } 19 \cdot 4+2 \cdot 3 \\
\text { (7) } 20 \cdot 2+2 \cdot 9\end{array}$ & 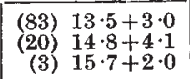 & $\begin{array}{l}0.79 \\
0.79 \\
0.77\end{array}$ \\
\hline
\end{tabular}

* Numbers in brackets indicate the number of determinations. † Calcium and magnesium concentrations expressed in molarities.

As our purpose is to offer a reliable micro-method for the determination of low concentrations of calcium and magnesium in small amounts of biological fluids, it is interesting to compare our results with the few found in the literature. Calcium values are in full agreement with those of Clark and Craig ${ }^{3}$ This, however, is not the case for the magnesium determinations ; Clark and Craig found $27.5 \mathrm{mgm}$. per $100 \mathrm{gm}$. of hæmolymph, Tobias ${ }^{4}$ gives a value of only $7 \mathrm{mgm}$. per $100 \mathrm{gm}$. of hæmolymph, both for P.americana. In our view the dry-ashing of the hæmolymph as used by both authors may lead to erroneous results, as by this procedure organic phosphorus is converted to possibly interfering inorganic phosphates. However, differences in the animal material may also have played a part, although we do not consider this very probable.

Our experiments permit no conclusion as to the state in which the elements investigated are present.

A more detailed report of our investigations will be published elsewhere.

\section{K. VAN ASPEREN \\ IDA VAN ESCH}

Laboratory for Research on Biocides,

National Council for Agricultural Research T.N.O. Vondellaan 6, Utrecht. July 20.

1 Holtz, A. H., Ned. Jïjdschr. Geneeskunde, 95, 2420 (1951).

${ }^{2}$ Buckley, jun., F. S., Gibson, J. G., and Bortolotti, T. R., J. Lab. Clin. Med., 38, 751 (1951).

${ }^{3}$ Clark, E. W., and Craig, R., Physiol. Kool., 26, 100 (1953)

" Tobias, J. M., J. Cell. Comp. Physiol., 31, 125 (1948).

\section{A Chromatographic Separation of the Aminofluorescein Isomers}

IN the preparation of aminofluorescein by the condensation of 4-nitrophthalic acid and resorcinol followed by reduction, two isomers $(A)$ and $(B)$ are formed at the condensation stage, and these must

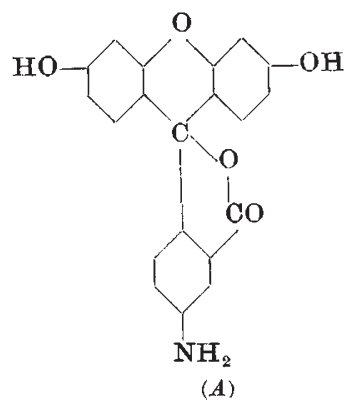

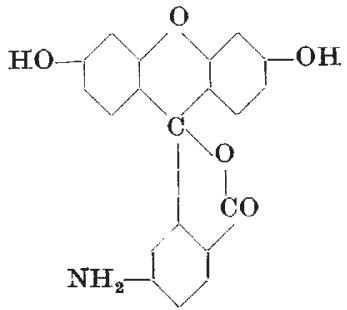

(A)

(B) 